\title{
HUKUKI AILE KARARNAMESI: Reformasi dan Konstitusionalisasi Hukum Keluarga Islam di Turki
}

\author{
Chamim Tohari \\ Marmara University Istanbul Turki \\ amimzone@yahoo.co.id
}

\begin{abstract}
Abstrak
Penelitian ini terfokus pada kajian aspek historis munculnya kitab Hukuki Aile Kararnamesi (HAK) yang dikhususkan untuk. menjawab beberapa poin permasalahan tentanglatar belakang munculnya kitab Hukuki Aile Kararnamesi, karakteristik. pemikiran figh hingga pemberlakuannya sebagai konstitusi resmi negara,metode penyusunan kitab tersebut,sertaperanan dan eksistensi kitab tersebut ditengah diundangkannya hukum keluarga sekuler yang diterapkan setelahnya di negara Turki modern. Penulis menggunakan pendekatan analisis historis dalam mendeskripsikan hasil penelitian ini. Hasil penelitian ini adalab: (1) Kodifikasi hukum keluarga Islam di Turki adalah sebagai konsekwensi dari adanya reformasi bukum yang dilakukan pemerintah Usmaniyah pada masa Sultan Abdul Hamid akibat desakan modernisasi dan sekulerisasi yang mempengarubi wilayah-wilayah Turki. Adapun karakteristik kitab HAK yang
\end{abstract}


menjadi kekhususannya adalab keberlakuannya yang universal, tidak terikat pada satu mazhab, dan realistis;(2) Metode penyusunan kitab menggunakan metode talfiq, yakni menggunakan beberapa pemikiran bukum para ulama mazhab dan memilih salah satu berdasarkan pendapat yang paling relevan dengan kebutuban masyarakat yang dihadapi; dan(3) Kitab HAK hingga kini masih berfungsi sebagai sumber bukum pernikahan dan diterapkan oleh masyarakat Turki modern bersamaan dengan penerapan The Civil Code, yakni hukum keluarga sekuler yang diterapkan oleh pemerintah Turki sejak tahun 1926 silam.

Keywords: Hukuki Aile Kararnamesi, The Civil Code, Turki Usmaniyah.

\begin{abstract}
This research focused to the study about Hukuki Aile Kararmnamesi $(H A K)$ in the historical aspect which is specialized to answer several main problems about background, characteristic of the figh thought, implementation as a legal constitution in Turkey, the methods of codification, and its role and existence between legislation of the family secular law in the early modern state of Turkey. The researcher use a historical analysis approach as method to describe the result of this research. The result of this research were: (1) The background of the codification of Islamic Family Law in Turkey is a condition of the Ottoman empire which had reformation in the law field in the Sultan Abdul Hamid period. Cause of the reformation of law is a pressure to the modernization and secularization by West states to the countries under Ottoman's authority. Afterwards, the universal, unbounded to the one or more of mazhab thoughts, and realistic maybe can be mentioned as the characteristic of the HAK book; (2) The method of codification is Talfiq method. It is using several opinions from the muslem scholars in the difference sects, then choose one of the most relevan opinion of law which is needed by the citizen; and (3) Untill now the book (HAK) still implementated by the moslem society in the modern state of Turkey together with the legislation of The Civil Code, a secular family law as substitute of this book since the year 1926 ago.
\end{abstract}

Kata Kunci:Hukuki Aile Kararnamesi, The Civil Code, Turki Usmaniyah. 


\section{A. Pendahuluan}

Apabila dicermati dari sisi historisnya, hukum Islam di Turki telah mengalami perjalanan yang dapat dikatakan sangat panjang, yakni sejak berdirinya dinasti Seljuk yang memimpin beberapa wilayah Turki. Hukum Islam pada masa tersebut belum menemukan bentuknya meskipun sudah diterapkan baik oleh individu maupun melalui perintah dari penguasa Seljuk. Kemudian pada masa berdirinya Dinasti Usmaniyah sekitar tahun 1299 M hukum Islam terus digunakan sebagai hukum yang ditaati dan dilaksanakan sebagai pedoman hidup oleh rakyat dan penguasa. Hal ini dikarenakan kekuatan dan legitimasi kerajaan Usmaniyah dibangun berlandaskan ajaran syari'ah Islam. ${ }^{1}$ Namun sebagaimana pada masa Seljuk, pada masa awal Usmaniyah pun hukum Islam masih belum terkodifikasi dengan baik, lebih-lebih sebagai konstitusi resmi negara.Karena hukum yang diterapkan dimasa Turki Usmaniyah adalah hukum Islam yang dijalankan oleh seorang mufti kerajaan (Syaikhul Islam) yang berfungsi sebagai hakim dan penasehat Sultan. Pada masa ini juga dikenal bentuk hukum yang disebut qanun, yakni hukum yang dibuat oleh Sultan atas masalah yang tidak terdapat dalam sumber hukum Islam seperti masalah-masalah pertanahan dan kriminal. ${ }^{2}$

Modernisasi di Turki yang puncaknya terjadi pada pertengahan abad ke-19 telah merubah Turki dari bentuk negara tradisional menjadi negara modern yang sejajar dengan negaranegara Barat. Modernisasi tersebut tidak luput dari peranan banyaknya para sarjana Turki yang mengenyam pendidikan Barat dan berpikiran modern. Pengaruh Westernisasi sangat tampak setidaknya pada produk reformasi undang-undang di negara tersebut. Pada akhir kekuasaan Usmaniyah, dimana Turki memasuki masa transisi dari negara yang menonjolkan keislamannya menuju sekulerisasi, hukum Islam mulai ditata

${ }^{1}$ Seval Yildirim, "Aftermath of a Revolution: A Case Study of Turkish Family law", Jurnal Peace International Law, vol. 17,2005, hlm. 5.

${ }^{2}$ Ibid. 
dengan baik dan diatur keberlakuannya dengan menyesuaikan dengan sistem hukum modern.

Hal ini terbukti dengan munculnya produk-produk hukum Islam hasil karya ulama Turki yang sukses menjadi bagian dari konstitusi resmi negara, yakni kitab Majallah al-Abkâm alAdliyah dan Hukuki Aile Kararnamesi. Kedua kitab tersebut harus diakui sebagai inspirasi bagi dunia Islam modern atas munculnya gerakan kodifikasi hukum Islam sekaligus sebagai contoh konstitusionalisasi hukum Islam dengan sistem perundangundangan modern. Meskipun, tentu saja sebagai hasil karya manusia tidak lepas dari kekurangan-kekurangan yang dapat dikritisi secara ilmiah.

Penelitian ini dikhususkan untuk mengkaji aspek historis munculnya kitab Hukuki Aile Kararnamesi terutama tentang beberapa poin yang menyangkut latar belakang dan metode penyusunan kitab tersebut. Untuk membatasi objek kajian, penelitian ini dikhususkan untuk menjawab beberapa poin yang menjadi rumusan permasalahan berikut: Pertama, aspek-aspek kesejarahan mulai dari munculnya kitab Hukuki Aile Kararnamesi hingga pemberlakuannya sebagai konstitusi resmi negara; Kedua, metode penyusunan kitab tersebut berikut kritikan-kritikan yang ditujukan kepadanya.Ketiga, peranan kitab Hukuki Aile Kararnamesi terhadap hukum keluarga yang diterapkan setelahnya di negara Turki modern. Penulis menggunakan pendekatan analisis historis dalam mendeskripsikan hasil penelitian ini.

\section{B. Pembahasan}

\section{Latar Belakang}

Sebelum masa reformasi hukum di Turki, secara umum hukum yang berlaku di Turki pada masa kesultanan Usmaniyah ada dua, yakni Hukum Syari'ah dan Hukum Sultan. Hukum Syari'ah digunakan untuk mengatur masalah-masalah dalam ranah privat atau perdata seperti hak-hak individual, hukum keluarga, hukum 
kewarisan, hukum perdagangan dan muamalah, serta hak-hak kelompok minoritas. Sementara itu bidang hukum lainnya dalam ranah publik seperti hukum pajak, hukum administrasi, hukum kependudukan serta hukum pidana yang tidak diatur secara detail dalam hukum Islam diatur melalui qanun (undang-undang) yang dibuat oleh Sultan berdasarkan hukum adat yang berlaku di negeri Ottoman tersebut. ${ }^{3}$ Sedangkan mengenai praktik dalam wilayah hukum keluarga Islam, rakyat Turki telah menganut hukum tersebut berdasarkan fiqh mazhab Hanafi dalam kurun waktu yang relatif lama. Karena itu sebelum kitab $H A K$ dikonstitusikan menjadi undang-undang resmi negara, para hakim di kesultanan Turki Usmaniyah memutuskan perkara dengan mendasarkan pada fiqh mazhab Hanafi. ${ }^{4}$

Pada awal abad ke-18 kerajaan Turki Usmaniyah memulai peperangannya dengan negara-negara Eropa dimana kondisi tersebut berpengaruh terhadap keterpurukan pemerintah terutama di bidang ekonomi.dalam keadaan tersebut Turki mulai menyadari akan pentingnya melakukan reformasi di segala bidang yang tertinggal seperti bidang sains dan teknologi. Kala itu bidang yang juga mendapat perhatian serius dari pemerintah Turki adalah bidang hukum. Karena itu dilakukanlah reformasi total dibidang hukum dan perundang-undangan (tanzimat) sejak tahun $1839 \mathrm{M}$. akibat reformasi hukum tersebut Turki secara berangsur-angsur mulai menjelma menjadi negara sekuler meskipun pada masa itu sekulerisme masih terbatas dalam beberapa bidang hukum saja. Sekulerisme di bidang hukum tampak pada diadopsinya hukum-hukum Barat secara besar-besaran, meskipun dalam bidang hukum keluarga dan muamalah hukum Islam masih dipertahankan. Menurut Necmeddin Guney, tumbuh suburnya sekulerisme hukum di Turki disebabkan oleh semakin banyaknya

${ }^{3}$ Sukru Hanioglu, A Brief History of the Late Ottoman Empire, (Pronceton: Princeton University Press, 2008), hlm. 18.

${ }^{4}$ Necmeddin Guney, "The First Codification Of Islamic Family Law: The Ottoman Decree On Family Law (1917)", Jurnal Ulumuddin Universitas Mubammadiyah Malang, Edisi Januari-Juni 2013, hlm. 149. 
birokrat yang berpikiran Barat serta tekanan yang luar biasa besarnya dari negara-negara Barat. ${ }^{5}$ Dalam hal ini salah satu kepentingan Barat adalah agar segera diterapkan sistem negara sekuler di Turki demi melindungi kepentingan warga negara minoritas non muslim yang sudah kehilangan hak hukumnya karena selalu harus mengikuti aturan-aturan hukum Islam yang selama ini diterapkan oleh pemerintah Turki Usmaniyah.

Kitab $H A K$ disusun dalam konteks dimana para ulama dan cendikiawan Turki terpecah menjadi setidaknya tiga kelompok. Kelompok pertama adalah para ulama dan cendikiawan konservatif yang fanatik dan menginginkan hukum Islam perspektif mazhab Hanafi tetap digunakan sebagai hukum resmi negara. Kelompok kedua adalah ulama dan cendikiawan berpikiran modern yang selalu menginginkan perubahan hukum di Turki meniru perkembangan zaman dan terbuka dengan pemikiran Barat (Western-minded intelectuals). Kelompok ketiga adalah pada ulama dan cendikiawan yang menjadi bagian dari pemerintah dan menempati posisi birokrasi pembuat kebijakan. Mereka ini berapa pada posisi tengah antara kelompok konservatif dan kelompok modernis. Kelompok ketiga inilah yang akhirnya memutuskan bahwa Turki terbuka dan menerima pengaruh pemikiran Barat, tetapi terbatas hanya pada bidang sains dan teknologi, termasuk di bidang hukum.

Reformasi hukum di Turki berlangsung sekitar abad ke-19 hingga abad ke-20. Pada kurun waktu tersebut banyak undangundang baru dibuat dan untuk pertama kalinya sebuah pengadilan sekuler didirikan dimana pengadilan yang baru berdiri tersebut mempunyai kedudukan yang sama dengan pengadilan syari'ah atau yang disebut dengan Mahkamah Syari'ah. Meskipun secara umum kodifikasi undang-undang pada era tanzimat mengacu pada model legislasi Barat - bahkan banyak materi hukum Barat yang langsung ditransformasikan ke dalam undang-undang baru di Turki - kala itu, namun dalam beberapa bidang hukum materi

${ }^{5}$ Ibid, hlm. 149. 
perundang-undangan masih tetap diambil dari hukum Islam, meskipun model penyusunannya dilakukan berdasarkan bentuk legislasi sistem hukum Barat. Para sejarawan menyebutkan bahwa keberhasilan hukum Islam bertahan bahkan hingga dikonstitusikan secara modern ke dalam sistem hukum Turki Usmaniyah sebenarnya tidak terlepas dari perjuangan seorang ulama konservatif yang sangat berpengaruh pada zamannya, yakni Ammet Cevdet Pasha (w. 1312 H/1895 M).

Konstitusionalisasi hukum di Turki sebagai hasil dari reformasi hukum (tanzimat) yang dilakukan oleh Sultan Abdul Hamid pada masa kesultanan TurkiUsmaniyah dapat dikelompokkan menjadi dua bentuk:

Pertama, adalah konstitusionalisasi hukum Barat ke dalam perundang-undangan Turki secara total. Bentuk yang pertama ini dilakukan dengan cara mengadopsi materi undang-undang hukum Prancis secara keseluruhan (the complete adoption). Hukum-hukum yang termasuk dalam kategori ini diantaranya: (1) Kanunamei Ticaret (The Ottoman Commercial Code) pada tahun 1850 yang diadopsi dari hukum bisnis Prancis; (2) Usuli Mubakemei Ticaret Nizamnamesi (The Code of Commercial Procedure) yang diambil dari hukum Prancis pada tahun 1861; (3) Ticaret Bahriye Kanunnamesi (The Code of Maritime Commerce) pada tahun 1861; serta (4) Usuli Mubakemati Ceraiye Kanunu (The Code of Civil Procedure) pada tahun 1879. Kesemua undang-undang yang berlaku pada ranah publik (the public law) tersebut diadopsi secara total dari undangundang Prancis. ${ }^{6}$

Kedua, adalah konstitusionalisasi HukumIslam ke dalam perundang-undangan di Turki. Bentuk yang kedua ini dilakukan hanya pada bidang hukum muamalah dan hukum keluarga saja (the pattern on codification).Kedua bidang hukum yang diadopsi dari hukum Islam dan diberlakukan pada ranah privat (the privat law) tersebut adalah: (1) Majallah al-Abkam al-Adliyah yang berlaku

${ }^{6}$ J.N.D. Anderson, "The Significance of Islamic Law in the World Today", The American Journal of Comparative Law, vol. 9, no. 2, Spring, 1996, hlm. 188. 
sejak tahun 1869 M hingga tahun 1926 M; (2) Hukuki Aile Kararnamesi yang berlaku sejak 1917 M hingga tahun 1919 M. ${ }^{7}$

Selanjutnya tulisan ini akan mengkaji tentang seluk beluk serta hal-halyang berkaitan dengan kodifikasi hukum Islam yang kedua tersebut.

\section{Karaktristik}

Sebagai konstitusi resmi negara, kitab $H A K$ memiliki beberapa kekhususan yang penulis sebut sebagai karakteristik yang tidak dimiliki kitab-kitab fiqh sebelumnya atau bahkan sesudahnya. Diantara kekhususan tersebut adalah:

1. Qhiversal

Dikatakan universal karena barangkali ini adalah satusatunya kitab hukum keluarga Islam pertama sepanjang sejarah yang diberlakukan secara lintas agama. Kitab $H A K$ yang notabene bersumber dari literatur-literatur jurisprudensi Islam dalam semua mazhab jika dilihat dari sisi pemberlakuannya memang sangat menarik. Karena tidak hanya berlaku untuk warga negara beragama Islam saja, tetapi untuk seluruh warga negara di wilayah-wilayah dibawah kekuasaan imperium Turki Usmaniyah, baik bagi mereka yang muslim maupun non muslim. ${ }^{8}$

Sebagaimana diketahui bahwa Turki Usmaniyah adalah sebuah imperium cosmopolitan yang terdiri dari banyak suku bangsa dan agama. Karena itu sangat penting bagi pemerintah untuk tetap menjaga keutuhan dan kesatuan bangsa. Salam satu instrumennya adalah melalui politik hukum yang tepat. Karena itu kontrol terhadap keragaman melalui hukum menjadi tali yang mempererat persatuan bagi warga negara Turki. Dalam sejarah hukum Islam, $H A K$ merupakan fenomena pertama dimana

${ }^{7}$ Sami Erdem, Mecelle, The Encyclopedia of the Ottoman Empire, (New York: Infobase Publishing, 2009), hlm. 356.

${ }^{8}$ Ahmet Yasin Kucuktiryaki, Osmanli Devletinde Tanzimat Sonrasi Aile H kuku Alaninda Gelismeler ve Hukuki Aile Kararnamesi, Tesis Master Hukum Islam, Gazi Universitesi, tahun 2009, hlm. 191. 
hukum Islam diundangkan dan dipergunakan oleh warga negara berbagai agama. Dan ini menjadi keunikan kitab $H A K$, meskipun usia keberlakuannya tidak berlangsung lama.

Pemberlakuan $H A K$ secara universal tersebut berakibat pada proses hukum hanya pada satu institusi peradilan saja, yakni Mahkamah Syariah. Karena itu baik warga muslim maupun non muslim hanya dapat menyelesaikan perkara hukumnya di Pengadilan Mahkamah Syariah.?

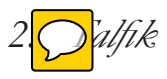

Talfik yang dimaksud dalam tulisan ini adalah implementasi fiqh lintas mazhab. ${ }^{10}$ Negara Turki Usmaniyah sebagaimana yang dikenal dalam sejarah merupakan negara yang sudah ratusan tahun menganut mazhab Hanafi sebagai satu-satunya mazhab resmi negara. Adalah tabu rasanya menggunakan figh dari mazhab lain di negara tersebut pada masa itu, lebih-lebih menjadikannya sebagai konstitusi resmi negara. Sebagaimana kitab Majallah alAbkâm al-Adliyah yang terlebih dahulu dikonstitusikan sebelum kitab $H A K$, secara penuh menggunakan fiqh Hanafi sebagai sumber materi undang-undangnya. Hal ini berbeda dengan kitab $H A K$ yang disusun dengan mengakomodir pandanganpandangan fiqh semua mazhab besar seperti mazhab Maliki, Syafi'i dan Hanbali, selain mazhab Hanafi. Ini adalah keunikan yang lain dari kitab $H A K$ setelah keberlakuannya yang universal.

Menurut hemat penulis, setidaknya ada dua hal penting mengapa HAK disusun secara talfik (lintas mazhab). Pertama, karena $H A K$ dipersiapkan untuk diberlakukan di seluruh wilayah kekuasaan Turki yang mana penduduknya menganut bermacam-

${ }^{9}$ Mehmet Akif Aydin, Hukuki Aile Kararnamesi, DIA, Jilid 18, hlm. 316.

${ }^{10}$ Dalam istilah ushul fiqh, talfik diartikan sebagai menggunakan lebih dari satu pendapat mazhab dalam suatu masalah hukum, tanpa mengingkari pendapat dari mazhab lainnya. Jumhur ulama berpendapat bahwa talfik diperbolehkan dalam perkara-perkara yang tidak bertentangan dengan ijma'. Untuk lebih jelasnya lihat Wahbah Zuhaili, Ilm al-Ushul Figh, (Kairo: Dar al-Fikr, 1986), hlm. 11421143. 
macam mazhab. Kedua, pada era reformasi hukum di Turki (tanzimat) telah terjadi perubahan besar dalam bidang pemikiran hukum dimana orang Turki mulai terbuka dengan berbagai model pemikiran Barat dan sekulerisme. Kondisi tersebut sedikit banyak memudarkan fanatisme mazhab pada sebagian ulama dan cendikiawan Turki, terutama pada saat menjelang akhir keruntuhan kerajaan Turki Usmaniyah. Hal ini juga sebagai konsekwensi dari pengaruh pemikiran modernisme yang banyak dijumpai pada diri tokoh-tokoh ulama dan sarjana di Turki.

$P^{\text {Realistis }}$

Maksud realistis disini adalah kitab $H A K$ tidak sekedar disusun dengan mengedepankan aspek teoritis semata, tetapi lebih dari itu sebagai jawaban dari problem sosial yang dihadapi. Sebagaimana diketahui bahwa $H A K$ disusun pada masa-masa peperangan dimana kondisi sosial politik yang tidak stabil serta permasalahan yang dihadapi turut mempengaruhi cara berpikir para ulama dan panitia khusus yang ditugaskan menyusun kitab tersebut. Untuk menjawab permasalahan yang dihadapi, adakalanya figh mazhab Hanafi saja tidak selalu relevan dengan keadaan yang dibutuhkan masyarakat masa itu. Sehingga pemberlakuan fiqh lintas mazhab adalah solusinya.

Sebagai contohnya, dalam mazhab Hanafi seorang istri dibolehkan mengajukan gugatan cerai hanya dalam kondisi tertentu dan dibatasi dengan alasan yang sangat sempit, seperti karena suami menderita penyakit kelamin yang tidak dapat sembuh. Dalam $H A K$, alasan tersebut diperluas dengan memasukkan hilangnya suami atau perginya suami dalam waktu lama tanpa kabar berita. Pandangan seperti itu tentu sangat dipengaruhi oleh kondisi sosial masa itu dimana banyak suami yang pergi berperang dan tak lagi pulang, tidak lagi ada kabar tentang keberadaannya. 
${ }^{11}$ Contoh yang lain adalah tentang dibolehkannya seorang laki-laki beristri lebih dari satu. Ketentuan dalam $H A K$ dalam masalah ini tentu tepat sekali dimana pada masa tersebut, yakni masa-masa dimana rakyat Turki sedang berjuang mati-matian dalam pertempuran panjang guna menyelamatkan negerinya dari penjajahan Barat dan musuh-musuhnya. Perang tersebut banyak memakan korban dan banyak perempuan menjanda akibat ditinggal suaminya yang tewas dalam perang.

\section{Metode}

Kitab $H A K$ disusun dalam bahasa Osmanli ${ }^{12}$ dan terdiri dari 157 pasal. Kitab tersebut terdiri dari dua buku dan keduanya memuat tentang hukum pernikahan dan percraian. Buku pertama terdrii dari enam bab, dan buku kedua terdiri dari tiga bab. ${ }^{13}$ Beberapa kelebihan kitab $H A K$ yang bisa disebutkan disini antara lain:

Pertama, kitab HAKtelah memenuhi standar sebagai sebuah kitab undang-undang hukum keluarga pada masa tersebut. Karena itu, barangkali kitab ini berlaku untuk seluruh warga negara dibawah kekuasaan khilafah Usmaniyah, muslim maupun non muslim. Undang-undang dalam kitab tersebut ditegakkan dibawah institusi Pengadilan Mahkamah Syariah. ${ }^{14}$

Kedua, kitab $H A K$ mengakomodasi pemikiran beberapa mazhab dalam fiqh Islam. Selain itu kitab tersebut sangat terbuka dengan pemikiran dari luar Islam, sehingga dapat dikatakan bahwa basic pendekatan yang digunakan adalah prinsip kebebasan berpikir dengan pandangan-pandangan objektif. Modernisme

${ }^{11}$ Lihat Ahmet Yasin Kucuktiryaki, Osmanli Devletinde Tanzimat..., hlm. 190-192.

${ }^{12}$ Bahasa Osmanli adalah bahasa Turki yang ditulis dengan menggun kan alphabet Arab.

${ }^{13}$ Ekrem Bugra Ekinci, Osmanli Hukuku: Adalet ve Mulk, (Istanbul: Ari Sanat, 2008), hlm. 574.

${ }^{14}$ Ilber Ortayli, Family: Encyclopedia of the Ottoman Empire, (New York: Infobase Publishing, 2009), hlm. 215. 
pemikiran hukum yang tertuang dalam kitab $H A K$ menjadikannya sebagai kitab yang sesuai dengan kebutuhan masyarakat modern kala itu.

Sepanjang sejarah kodifikasi hukum di Turki, untuk pertama kalinya sebuah kitab undang-undang disusun dengan metode talfiq atah tahayyur, yakni mengkaji pemikiran semua mazhab figh untuk dipilih pendapat yang paling sesuai dengan keadaan atau kebutuhan. Salah satu contoh penggunaan pemikiran hukum yang termuat dalam $H A K$ diluar mazhab Hanafi sebagai mazhab resmi negara adalah dalam masalah seorang istri bilamana suaminya menghilang dan tidak kembali lagi tanpa ada kabar, maka status pernikahannya hendaknya diputuskan oleh hakim melalui pengadilan. Ini adalah pendapat dari mazhab Syafi'i yang kemudian dicantumkan sebagai bagian dari materi hukum $H A K$ pada masal $122-126 .{ }^{15}$

Realitas bahwa $H A K$ disusun secara talfiq menunjukkan bukti keterlibatan para sarjana progresif Turki dalam penyusunan kitab tersebut, dimana mereka berprinsip untuk tidak mengikatkan diri pada salah satu mazhab yang ada sebagaimana mayoritas ulama dan sarjana konservatif Turki yang menjadikan mazhab Hanafi sebagai panutan dalam berislam. Selain itu, bisa jadi kitab $H A K$ sebagai bentuk reaksi dari para ulama progresif yang mencoba mengimbangi keberadaan dominasi para ulama konservatif pasca diberlakukannya kitab Majallah al-Abkam alAdliyah yang hanya mengakomodasi satu pemikiran mazhab saja, yakni mazhab Hanafi.

\section{Isi Kitab $H A K$}

Ada tiga hal penting yang hendak penulis kaji tentang isi kitab $H A K$, yakni:

Pertama, tentang batas usia minimum pernikahan. Dewan penyusun kitab $H A K$ dalam memutuskan masalah ini menggunakan cara talfiq, yakni merujuk kepada pendapat beberapa

${ }^{15}$ Seval Yildirim, Aftermath of a Revolution..., hlm. 355. 
mazab fiqh. Kitab $H A K$ mengatur batas usia minimum seseorang diperbolehkan menikah adalah usia 18 tahun untuk laki-laki dan 17 tahun untuk perempuan. Perempuan diperbolehkan menikah hanya dengan izin dari pengadilan. Karena itu setiap perempuan yang hendak melakukan pernikahan harus mendaftarkan diri terlebih dahulu ke pengadilan dengan didampingi walinya dan menunggu keputusan dari hakim. Jika dalam kondisi tertentu hakim tidak member izin, maka perempuan yang berusia 17 tahun ke atas tetap dapat melakukan pernikahan secara tidak resmi (sirr). ${ }^{16}$ Dalam hal tidak perlunya izin wali maupun hakim bagi perempuan yang sudah dianggap dewasa tersebut tampak bahwa $H A K$ mengikuti pemikiran figh mazhab Hanafi. ${ }^{17}$

Kedua, tentang polygami. Meskipun $H A K$ mengizinkan seorang suami beristri hingga empat, namun $H A K$ memberikan wewenang kepada istri untuk member izin atau menolak untuk dimadu. ${ }^{18}$ Selain itu dalam akad pernikahan, $H A K$ mengatur adanya perjanjian atau kontrak pernikahan dimana apabila suami melanggar perjanjian tersebut maka jatuhlah talak. ${ }^{19}$ Pelanggaran atas perjanjian dalam akad nikah tersebut tidak berarti talak secara otomatis jatuh, tetapi harus melalui proses pengadilan dan putusan hakim. Ktentuan seperti disebutkan di atas diambil dari mazhab Hanbali, karena dalam mazhab Hanafi yang menjadi mazhab resmi negara Turki tidak terdapat ketentuan tersebut.

Ketiga, tentang perceraian. Dalam fiqh Hanafi, alasan seorang istri diperbolehkan mengajukan perceraian sangat dibatasi hanya pada kasus tertentu semisal masalah suami

${ }^{16}$ Pasal 8 HAK. Lihat Nicola Van Os, Polygami before and after: The Introdu tion of the Swiss Civil Code in Turkey, ( New York: I.B. Tauris, 2007), hlm. 190.

${ }^{17}$ Ibn Rusyd al-Qurthubi, Bidâyah al-Mujtahis wa Nihâyah al-Muqtashid, (Kairo: Maktabah al-Taufiqiyah, t.th., jilid 2), hlm 22.

${ }^{18}$ Pasal 14 dan $38 H A K$.

${ }^{19}$ Perjanjian dalam akad nikah biasa disebut ta'lik talak. Ta'lik talak ad lah suatu perjanjian yang dibuat pada saat akad nikah berlangsung yang isinya dimaksudkan untuk melindungi hak-hak istri. Substansi ta'lik talak tidak boleh bertentangan dengan syariat Islam. Apabila perjanjian ta'lik talak dilanggar oleh suami, maka konsekwensinya talak akan dijatuhkan dengan putusan hakim. 


\section{Chamim Tohari}

impoten atau mengidap penyakit kelamin atau penyakit menular yang jika rumah tangga terus dilangsungkan akan berakibat buruk dan merugikan istri. Di dalam $H A K$ alasan tersebut diperluas dengan memasukkan masalah perginya suami dalam waktu yang lama tanpa kabar keberadaannya. Dalam kondisi tersebut istri diperkenankan mengajukan perceraian ke pengadilan. Masalah lainnya tentang prceraian adalah tentang adanya unsur paksaan, yakni sebagamana pernikahan, perceraian pun dianggap tidak sah apabila dilakukan dengan adanya unsur paksaan, atau dilakukan dalam keadaan tidak sadar atau mabuk. ${ }^{20}$

\section{Pemberlakuan dan Penghapusan}

Kitab Hukuki Aile Karanamesi ( $H A K)$ merupakan bentuk konstitusionalisasi hukum Islam pertama dalam masalah hukum keluarga setelah sebelumnya disahkan kitab Majallah al-Abkam alAdliyah sebagai kitab undang-undang Negara Turki Usmaniyah dalam bidang muamalah. $H A K$ disahkan menjadi undang-undang sekaligus sebagai sumber hukum perdata Islam pertama dibidang pernikahan dan kewarisan pada tahun 1917 M. ${ }^{21}$ keberlakuan $H A K$ tidak hanya sebatas di Turki, tetapi diseluruh wilayah kekuasaan khilafah Usmaniyah yang mencakup negara-negara Balkan, Afrika Utara, dan Timur Tengah.

Namun sangat disayangkan bahwa keberlakuan kitab $H A K$ sangatlah singkat, yakni tidak lebih dari dua tahun saja.

${ }^{20}$ Pasal 57 dan 104 HAK.

${ }^{21}$ Ekrem Bugra Ekinci, Osmanli Hukuku..., hlm. 573. Menurut Nicola Van Os, sebelum munculnya $H A K$ sudah ada kodifikasi hukum keluarga Islam di Mesir yang semisal dengan $H A K$, yang dijadikan rujukan resmi negara dalam memutuskan perkara dibidang hukum keluarga. Adalah Muhammad Qadri Pasha (w. 1888) yang telah menyusun sebuah draft undang-undang hukum keluarga Islam di Mesir.draft tersebut bernama al-Ahkâm al-Syar'iyyah fî al-Ahwâl al-Syahsiyyah. Draft tersebut terdiri dari dua bagian yang masing-masing memuat materi hukum pernikahan dan hukum kewarisan. Meskipun draft kitab tersebut tidak pernah secara resmi disahkan sebagai undang-undang sebagaimana $H A K$, namun kitab tersebut telah lama dikenal sebagai sumber dan dasar putusan para qadhi di beberapa negara Arab seperti Mesir dan Palestina. Lihat Nicola Van Os, Polygami before and after, hlm. 183. 
Kitab tersebut diresmikan menjadi undang-undang negara Turki Usmaniyah hingga bulan Juni tahun 1919 M. setelah penghapusan keberlakuan HAK, sebagai penggantinya diberlakukan undangundang sementara hingga masa transisi pemerintahan dari bentuk khilafah menjadi republik berakhir.

Salah satu alasan penghapusan $H A K$ adalah karena beban bagi warga negara non muslim yang kehilangan haknya untuk menerapkan doktrin ajaran agamanya dalam bidang hukum keluarga. Karena itu, sebagaimana diketahui, keberlakuan $H A K$ tidak hanya untuk umat muslim saja, tetapi untuk seluruh warga negara, muslim maupun non muslim. ${ }^{22}$ Selain itu, hukum acara yang ada di pengadilan dikhususkan hanya untuk penegakan $H A K$, sehingga tidak tersedia hukum acara peradilan untuk pelaksanaan hukum keluarga bagi agama diluar Islam. Di samping itu, dalam dalam kndisi dimana pemerintah Turki berada pada keadaan yang sangat lemah, sangat mudah bagi negara-negara Barat untuk menekan Turki agar tidak memberlakukan hukum-hukum Islam dengan alasan menghargai warga ngara yang non muslim tersebut. Tetapi alasan terpenting dihapuskannya $H A K$ sbenarnya adalah karena adanya reaksi negatif dari para ulama konservatif yang tidak menghendaki Turki menerapkan aturan hukum Islam yang multi mazhab. Salah seorang yang disinyalir memainkan peran penting dicabutnya $H A K$ sebagai bagian dari konstitusi di Turki adalah Syeikh Mustafa Sabri Efendi yang ketika itu penduduki jabatan sebagai mufti besar kerajaan. Setelah pencabutan $H A K$, penggunaan undang-undang sementara berlangsung hingga tahun 1926 M setelah resmi disahkan undang-undang hukum perdata baru, yakni undang-undang hukum perdata sekuler yang diambil dari hukum perdata Swiss. ${ }^{23}$

Menurut Mehmet Akif Aydin, sisi yang menarik dari sejarah kelam $H A K$ adalah bahwa kitab ini masih tetap diberlakukan di

${ }^{22}$ Gulnihal Bozkurt, Ghayri Muslim Osmanli Vatandaslarinin Hukuki D rumu, (Ankara: TTK, 1996), hlm. 210-211.

${ }^{23}$ Nicola Van Os, Polygami before and after, hlm. 191. 
negara-negara bekas kekuasaan kerajaan Ottoman meskipun di Turki semdiri kitab tersebut telah ditarik keberlakuannya. Misalnya di Yordania, HAK diberlakukan hingga tahun 1951 M, sedangkan di Irak dan Syria $H A K$ berlaku hingga tahun 1953 M. Bahkan hingga hari ini $H A K$ masih tetap diberlakukan secara privat di negara Libanon, Palestina dan Israel. ${ }^{24}$

Terlepas dari kontek sejarah yang melingkupinya, kitab $H A K$ memiliki pengaruh penting dalam sejarah hukum Islam. Di antara pengaruh penting yang dapat dilihat hingga sekarang adalah semakin banyaknya legislasi hukum Islam dalam bentuk undang-undang yang kemudian difungsikan menjadi undangundang resmi negara oleh negara-negara berpenduduk mayoritas muslim seperti kodifikasi-kodifikasi hukum Islam yang terjadi di Indonesia. Dalam hal ini kitab $H A K$ seakan-akan menjadi inspirasi kebangkitan hukum Islam di negara-negara muslim di dunia hingga saat ini.

\section{Kritik Terhadap $H A K$}

Pakar hukum Islam Turki modern, Ekrem Bugra Ekinci, ketika mengkaji kitab $H A K$ menulis beberapa catatan yang menjadi kritikan atas kitab tersebut. Di antara poin yang paling penting dalam kritikannya adalah tentang ketidaklengkapan isi kitab $H A K$ dalam memuat bagian-bagian penting dalam hukum keluarga Islam seperti ketentuan hukum dalam hal mengasuh anak (hadhanab), wasiat (washiyah), serta masalah nafkah (nafaqah). Mnurutnya ketidaklengkapan cakupan hukum kitab tersebut bukan tanpa kesengajaan, tetapi karena adanya benturan kepentingan antara kelompok ulama konservatif yang menginginkan terwujudnya proses taqnin secara bertahap dan kelompok sekuler yang tidak menghendaki hukum keluarga Islam menjadi bagian dari konstitusi negara. Dalam pandangan Ekinci, komisi fatwa yang bertugas menyusun kitab $H A K$ sebenarnya berharap adanya

${ }^{24}$ Mehmet Akif Aydin, Hukuki Aile Kararnamesi, (DIA, Istanbul: ISAM Yayinlari, 1989, juz. 18), hlm. 314-318. 
penyempurnaan cakupan hukum dalam kitab $H A K$ pada masamasa berikutnya setelah diundangkan, namun harapan tersebut tidak pernah terwujud bahkan hingga keruntuhan kekhalifahan Turki Usmani.Ekinci menjelaskan bahwa sebenarnya usaha kea rah penyempurnaan kitab $H A K$ telah dilakukan oleh komisi yang bertugas menyusun kitab tersebut dengan telah disiapkannya draft tentang kitab al-nafaqah, tetapi draft tersebut tidak pernah menemukan momentumnya untuk dapat disahkan menjadi qanun hingga berakhirnya keberlakuan kitab $H A K$ di Turki. ${ }^{25}$

Namun demikian, kitab $H A K$ dari segi komposisi materinya tidak hanya sudah menunjukkan keterwakilan pemikiran hukum beberapa mazhab, ttapi juga keterwakilan pemikiran westernis dan nasionalis. Hal ini berbeda dengan kitab Majallah al-Ahkam al-Adliyah yang hanya merujuk pada satu mazhab saja, yakni mazhab Hanafi. Selain itu $H A K$ juga terbuka dengan konteks sosial yang menyertainya pada saat menyusunannya, seperti konteks sekularisasi dan modernisasi. ${ }^{26}$

Kritik lainnya dikemukakan oleh salah seorang ulama Turki, Sadruddin Efendi. Di antara beberapa poin penting kritiknya adalah: (1) Beberapa pasal dalam $H A K$ tidak sesuai dengan kemaslahatan dan kemanfaatan umat, bahkan terkesan menyulitkan dan terjebak pada masalah teknis administratif:, ${ }^{27}$ (2) Banyak pasal yang bertentangan dengan Kitab, Sunnah, ijma' dan qiyas; ${ }^{28}$ (3) Perbedaan pendapat dalam mazhab dan qaul ulama seolah-olah dianggap salah oleh $H A K$, karena qanun tersebut

${ }^{25}$ Ekinci, Osmanli Hukuku, hlm. 576.

${ }^{26} \mathrm{Ibid}$, hlm. 576.

${ }^{27}$ Misalnya pada pasal ke-6 HAK yang mensyaratkan bahwa pernik han harus menyertakan ijin dari hakim bilamana wali berhalangan. Sadruddin Efendi, Hukuki Aile ve Usulu Muhakemati Ser'iyye Kararnameleri Hakkinda, Istanbul: Mathba'ah Orhaniyah, t.th, hlm. 400-402.

${ }^{28} \mathrm{Ibid}, \mathrm{hlm}$. 382. Misalnya pasal $38 \mathrm{H} A \mathrm{~K}$ yang menyatakan bahwa jika seseorang hendak menikah untuk yang kedua kalinya, maka harus mendapatkan izin dari istri pertama. Hal ini oleh Sadruddin Efendi dianggap bertentangan dengan nash dan ijma' yang tidak mensyaratkan izin dari istri dalam masalah poligami. 
tidak mengizinkan orang menggunakan pendapat lain diluar ketentuan dalam $H A K ;^{29}(4)$ Ketentuana-ketentuan dalam $H A K$ bertentangan dengan prinsip dan asas hukum modern; ${ }^{30}$ dan (5) Dari sisi teknik perundanganterdapat banyak kesalahan dan kekurangan pada sistematika penyusunannya, juga pada materi hukumnya. ${ }^{31}$

Selain kritikan tersebut di atas, masih ada lagi kritikan dari warga negara non muslim yang mempertanyakan penerapan $H A K$ untuk seluruh warga negara, termasuk warga non muslim. Sementara dalam masalah pernikahan dan perceraian warga non muslim memiliki aturan hukum sendiri yang mereka pegang, yang berbeda dengan aturan hukum dalam Islam. ${ }^{32}$ Demikian beberapa kritikan yang ditujukan kepada kitab $H A K$ sebagai hasil karya ulama Usmaniyah yang jika dilihat dari konteks sosiopolitik penyusunan kitab tersbut dapat dipahami keterbatasanketerbatasan yang ada. Dimana pada masa itu kekhalifahan Turki berada pada masa-masa menjelang keruntuhan, kekacauan dan kemiskinan akibat perang dialami seluruh penduduk negeri. Kondisi tersebut tentunya mempengaruhi jalannya proses legislasi dan penerapan hukum di Turki.

Dari penjelasan di atas berkaitan dengan kitab $H A K$ dan kompleksitasnya, yang perlu ditekankan adalah bahwa kodifikasi hukum keluarga Islam di Turki secara umum tidaklah terjadi secara netral dalam arti terbebas dari pengaruh polotok dan ideologi. Melainkan sebaliknya, sangat kental dengan kepentingan politik dan tarik ulur ideology, terutana ideology kelompok konservatif dan kelompok modernis. Akibat pemberlakuan kitab $H A K$ tersebut tidak sedikit rakyat Turki - terutama mereka yang tidak beragama Islam - yang merasa kehilangan tradisi mereka

\footnotetext{
${ }^{29}$ Ibid, hlm. 398-399.

${ }^{30}$ Ibid, hlm. 385-387.

${ }^{31}$ Ibid, hlm. 418-419.

${ }^{32}$ Ahmet Yasin Kucuktiryaki, Osmanli Devletinde Tanæimat Sonrasi Aile H kuku Alanindaki Gelismeler ve Hukuki Aile Karamanesi, (Tesis Institut Ilmu Sosial, Gazi Universitesi, tahun 2009, hlm. 195).
} 
Hukuki Aile Kararnamesi: Reformasi dan Konstitusionalisasi.....

yang berkaitan dengan seremonial pernikahan. Sebagai gantinya, diadopsilah undang-undang Swiss tentang hukum keluarga pada tahun 1926 untuk kemudian diterapkan di Turki modern sebagai hukum keluarga yang berlaku baik untuk kaum muslimin maupun non muslim. Penerapan Swiss Civil Code tersebut membuktikan kemenangan kaum modernis atas kaum konservatif yang selalu mengupayakan kembalinya hukum Islam sebagai hukum satusatunya di negeri Turki tersebut.

\section{Peranan Kitab $H A K$ Terhadap Hukum Keluarga di Turki Modern}

Berdasarkan hasil penelitian yang penulis lakukanmenunjukkan bahwa meskipun kitab $H A K$ telah dihapuskan keberlakuannya di Turki, namun pengaruhnya dibidang hukum keluarga khususnya pernikahan masih sangat besar hingga kini. Pengaruh yang nyata dan dapat dijelaskan di sini adalah bahwa existensi kitab $H A K$ hingga kini masih ada dan diterapkan oleh masyarakat Turki modern dan menjadi pelengkap hukum keluarga (The Civil Code) sekuler yang diterapkan oleh pemerintah Turki sejak tahun 1926 silam.

Setelah dihapusnya keberlakuan kitab $H A K$ di seluruh wilayah kekuasaan Turki, tidak berarti hukum keluarga Islam samasekali tidak diberlakukan di Turki terutama untuk saat ini. Hukum keluarga Islam tetap mendapatkan tempat dalam kehidupan masyarakat muslim Turki modern, hanya saja dalam ranah privat. Berdasarkan penelitian yang penulis lakukan sekitar tahun 2013-2014 di Istanbul Turki, pemberlakuan The Civil Code bahkan hanya dalam ranah pengadilan saja, sementara hukum yang sesungguhnya dianut dan dilaksanakan oleh rakyat Turki yang beragama Islam adalah hukum keluarga Islam yang dikenal dengan al-Ahwal al-Syahsiyah itu. Pemberlakuan hukum keluarga Islam secara privat menurut beberapa koresponden yang penulis temui justru lebih efektif dan diakui sebagai bagian dari hukum tidak tertulis negara Turki modern. Dengan 


\section{Chamim Tohari}

demikian hukum keluarga Islam di Turki tetap hidup bersamaan dengan perkembangan masyarakat muslim meskipun tidak mendapatkan legalitas dari negara. Keadaan yang demikian ini menjadikan hukum keluarga modern yang berlaku di Turki harus berkompromi dengan hukum keluarga Islam dan hukum-hukum syariah lainnya. Begitu pula dengan putusan-putusan hakim di pengadilan Turki yang harus mengakomodasi pengaruh hukum keluarga Islam sehingga putusan yang dibuat dapat diterima oleh masyarakat.

Hal ini adalah sebagaimana yang ditulis Ihsan Yilmaz, bahwa pada dasarnya pernikahan yang dilegalkan di negara Turki saat ini adalah pernikahan yang sesuai dengan The Civil Code. Mereka yang melakukan pernikahan dengan berdasarkan hukum keluarga Islam saja tidak dapat diakui legalitasnya oleh negara, bahkan terancam hukuman pidana. ${ }^{33}$ Karenanya umat Islam di Turki pada awalnya melaksanakan pernikahan berdasarkan The Civil Code, kemudian untuk menjamin keabsahannya dari sisi agama prosesi pernikahan dilanjutkan dengan menggunakan hukum keluarga Islam. ${ }^{34}$ Bahkan dalam banyak kasus, warga Turki masih banyak yang melakukan pernikahan secara hukum Islam tanpa melakukan registrasi atau berdasarkan aturan The Civil Code, dimana pernikahan tersebut dilakukan dihadapan seorang Imam atau ulama. Hal ini karena banyak rakyat Turki yang meyakini bahwa pernikahan berdasarkan aturan syar'i lebih legal dan sah daripada pernikahan berdasarkan Civil Code. ${ }^{35}$

${ }^{33}$ Ihsan Yilmaz, "Secular Law and the Emergence of Unofficial Tur ish Islamic Law",The Middle East Journal, Volume. 56, No. 1 (Winter, 2002), hlm. 113-131.

${ }^{34}$ Ibid.

${ }^{35}$ Ibid. berkaitan dengan hal ini, berdasarkan data hasil penelitian $\mathrm{K}$ menterian Agama Turki pada tahun 1970an dinyatakan bahwa pernikahan warga negara Turki yang dilakukan berdasarkan Civil Code mencapai 35,4\%, pernikahan yang dilakukan dengan menggunakan hukum Islam sebesar $15,0 \%$, dan pernikahan yang dilakukan dengan Civil Code dan hukum Islam sebesar 42,2\%. Sedangkan berdasarkan data hasil penelitian terbaru disebutkan bahwa dalam masyarakat urban, pernikahan Civil Code sebesar 13, 59\%, pernikahan dengan hukum Islam 
Realitas tentang pernikahan yang dilakukan oleh warga negara Turki modern ini menunjukkan bahwa meskipun pernikahan dengan berdasarkan Civil Code atau hukum pernikahan resmi negara telah dilakukan, namun oleh sebagian besar warga muslim di Turki pernikahan tersebut belum dipandang sah sebelum dilakukan pula dengan hukum Islam. Dan berdasarkan penelitian yang penulis lakukan, yang dimaksud dengan hukum Islam adalah hukum pernikahan dalam kitab $H A K$.

Penerapan kitab $H A K$ secara informal disamping kewajiban mematuhi The Civil Code sebagai hukum keluarga resmi negara sangat mungkin terjadi diantaranya karena dalam beberapa hal yang fundamental menyangkut hukum pernikahan, kitab HAK memiliki kesamaan dengan The Civil Code. Contoh yang bisa disebutkan disini adalah tentang larangan menikah lebih dari satu, dimana baik kitab HAK maupun Civil Code sama-sama melarang, dan bahkan bagi yang melanggar baik laki-laki maupun perempuan akan dikenakan hukuman pidana penjara antara enam bulan hingga tiga tahun. ${ }^{36}$ Kedua hukum tersebut sebenarnya sangat sesuai jika dilihat dari sudut pandang historis masyarakat Turki yang menganggap poligami adalah masalah yang tabu dan tidak layak dilakukan. Karena itu, tidak ada masalah dalam penerapannya ketika antara hukum Islam, hukum sekuler Barat dan hukum adat Turki menemui satu titik temu berkaitan dengan masalah tersebut. Contoh lainnya adalah tentang perceraian atau talaq. Dalam hukum pernikahan Islam talaq merupakan hal mubah tetapi tidak dianjurkan dan bahkan sedapat mungkin dicegah. Dalam Civil Code perceraian hanya dapat dilakukan dengan putusan hakim dengan berbagai pertimbangan yang pasti.

sebesar 3,09\%, dan pernikahan dengan menggunakan Civil Code dan hukum Islam mencapai $82,70 \%$. Sementara itu data yang diperoleh pada masyarakat rural yang melaksanakan pernikahan dengan Civil Code sebesar 5,11\%, pernikahan dengan hukum Islam sebesar 6,89\%, dan pernikahan dengan kedua hukum tersebut sebesar 87,38\%. Lihat State Planning Organizastion (SPO), Turk aile aractirmasi (Turkish Family Research), (Ankara: DPT, 1992), hlm. 42, tabel 31.

${ }^{36}$ Ihsan Yilmaz, Secular Law..., hlm. 124. 
Sementara itu dalam adat masyarakat Turki sendiri perceraian atau talaq adalah hal yang tidak disuka. Karena itu berdasarkan data angka perceraian di Turki relatif rendah. ${ }^{37}$ Dua contoh tersebut menunjukkan bahwa penghapusan dan penggantian keberlakuan kitab $H A K$ dengan The Civil Code tidak lantas menjadikan kitab $H A K$ sirna untuk selamanya di Turki, tetapi justru menjadi pelengkap hukum keluarga yang ada di Turki hingga saat ini.

\section{Simpulan}

Dari hasil penelitian ini terdapat beberapa poin yang dapat disimpulkan sebagai berikut:

Pertama, kodifikasi hukum keluarga Islam di Turki adalah sebagai konsekwensi dari adanya reformasi hukum yang dilakukan pemerintah Usmaniyah pada masa Sultan Abdul Hamid akibat desakan modernisasi dan sekulerisasi yang mempengaruhi wilayah-wilayah Turki. Sebagai produk modernisasi, kitab HAK mempunyai beberapa karakteristik yang menunjukkan modernitasnya, diantaranya keberlakuannya yang universal, pasalpasalnya disusun berdasarkan pemikiran lintas mazhab dan tidak terpaku hanya pada satu pemikiran mazhab, dan realistis dalam arti menjawab kebutuhan masyarakat Turki pada waktu itu.

Kedua, metode penyusunan kitab $H A K$ menggunakan metode yang dalam istilah ilmu ushul figh disebut dengan talfiq, yakni menggunakan beberapa pemikiran hukum para ulama mazhab dan memilih salah satu berdasarkan pendapat yang paling relevan dengan kebutuhan masyarakat yang dihadapi. Kritik terhadap kitab $H A K$ berkisar pada ketidaklengkapan cakupannya dalam menyelesaikan permasalahan hukum keluarga Islam. Selain itu, keberlakuannya yang universal - dalam arti kitab tersebut diberlakukan untuk semua rakyat baik yang muslim maupun non muslim - dianggap tidak sejalan dengan tradisi dan hak-hak

${ }^{37}$ Mary Zwahlen, Le divorce en Turquie: Contribution a l'etude de la reception du code civil suisse, (Divorce in Turkey: Contribution to the Study of the Reception of the Swiss Civil Code), (Geneve: Librarie Droz, 1981). 
kelompok warga negara non muslim. Sehingga secara umum dapat dikatakan bahwa selain kitab $H A K$ dipersepsikan sebagai dasar untuk menyelesaikan perkara hukum dibidang hukum keluarga, di sisi lain kitab tersebut mengundang kontraversi dan memunculkan permasalahan baru. Sehingga kitab dapat dimaklumi jika kitab tersebut berusia hanya tidak lebih dari dua tahun saja.

Ketiga, peranan kitab Hukuki Aile Kararnamesi terhadap hukum keluarga Turki modern adalah bahwa kitab $H A K$ hingga kini masih berfungsi sebagai sumber hukum pernikahan dan diterapkan oleh masyarakat Turki moderndalam posisinya sebagai penguat hukum keluarga (The Civil Code) sekuler yang diterapkan oleh pemerintah Turki sejak tahun 1926 silam. 


\section{Daftar Pustaka}

Al-Qurthubi, Ibn Rusyd.Bidâyah al-Mujtahis wa Nihâyah alMuqtashid, Kairo: Maktabah al-Taufiqiyah, t.th., jilid 2.

Anderson,J.N.D. "The Significance of Islamic Law in the World Today",The American Journal of Comparative Law, vol. 9, no. 2, Spring, 1996.

Aydin, Mehmet Akif.Hukuki Aile Kararnamesi, DIA, Istanbul: ISAM Yayinlari, 1989, juz. 18.

Bozkurt, Gulnihal.Ghayri Muslim Osmanli Vatandaslarinin Hukuki Durumu, Ankara: TTK, 1996.

Efendi, Sadruddin.Hukuki Aile ve Usulu Mubakemati Ser'iyye Kararnameleri Hakkinda, Istanbul: Mathba'ah Orhaniyah, t.th.

Ekinci,Ekrem Bugra.Osmanli Hukuku: Adalet ve Mulk, Istanbul: Ari Sanat, 2008.

Erdem, Sami.Mecelle: The Encyclopedia of the Ottoman Empire, New York: Infobase Publishing, 2009.

Guney, Necmeddin."The First Codification Of Islamic Family Law: The Ottoman Decree On Family Law (1917)",Jurnal Ulumuddin Universitas Muhammadiyah Malang, Edisi JanuariJuni 2013.

Hanioglu, Sukru. A Brief History of the Late Ottoman Empire, Pronceton: Princeton University Press, 2008.

Kucuktiryaki, Ahmet Yasin.Osmanli Devletinde Tanzimat Sonrasi Aile Hukuku Alaninda Gelismeler ve Hukuki Aile Kararnamesi, Tesis Master Hukum Islam, Gazi Universitesi, tahun 2009. 
Hukuki Aile Kararnamesi: Reformasi dan Konstitusionalisasi.....

Ortayli,Ilber.Family: Encyclopedia of the Ottoman Empire, New York: Infobase Publishing, 2009.

Os, Nicola Van.Polygami before and after: The Introduction of the Swiss Civil Code in Turkey, New York: I.B. Tauris, 2007.

Yildirim, Seval.Aftermath of a Revolution: A Case Study of Turkish Family Law, 2011.

Yilmaz, Ihsan."Secular Law and the Emergence of Unofficial Turkish Islamic Law", The Middle East Journal, Vol. 56, No. 1, Winter, 2002.

Zuhaili,Wahbah.Ilm al-Ushul Fiqh, Kairo: Dar al-Fikr, 1986.

Zwahlen, Mary.Le divorce en Turquie: Contribution a l'etude de la reception du code civil suisse, (Divorce in Turkey: Contribution to the Study of the Reception of the Swiss Civil Code), Geneve: Librarie Droz, 1981. 
Chamim Tohari 